\title{
Санубар Ганбарова
}

Азербайджанский университет туризма и менеджмента

\section{Дипломатическое п представительство Азербайджанской Демократической Республики в Армении в 1918-1920-е годы}

Кровавый военно-колониальный режим Российской империи не сумел уничтожить древнейшие традиции государственности азербайджанского народа. 28 мая 1918 года была создана Азербайджанская Демократическая Республика, которая являлась первым светским демократическим и правовым государством на мусульманском Востоке, а также в тюрко-исламском мире. Азербайджанская Демократическая Республика смогла просуществовать в напряженной и сложной социально-политической обстановке всего 23 месяца. К сожалению, не достигнув двухлетнего возраста, независимая Азербайджанская Республика подверглась нападению большевиков и была временно свергнута. Со дня образования правительство АДР проводило гибкую внешнюю политику и стремилась установить добрососедские отношения со всеми государствами региона.

9 июля 1919 года правительством Азербайджанской Демократической Республики была принята временная инструкция о секретариате Министерства иностранных дел. В период существования республики в ее столице городе Баку функционировали дипломатические представительства 16 государств, среди которых были, иностранные миссии США, Великобритании, Франции, Италии и т.д.

Одним из главных вопросов, постоянно привлекавших к себе внимание правительства Азербайджана, был вопрос о границах и отношениях с близкими соседями.

Одной из серьезных преград на пути укрепления Азербайджанской государственности в этот период стала экспансионистская и агрессорская политика Дашнакской Армении, которая пыталась присвоить исторические азербайджанские земли. Армения предъявляла необоснованные территориальные претензии к Карабаху, Нахичевану, Зангезуру и т.д. Несмотря на то, что вражественная позиция Армении по отношению к Азербайджану прослеживалась в течении всего периода существования АДР, Азербайджанской Республике ценою больших усилий и потерь все же удалось сохранить свою территориальную целостность.

В статье приводится информация об азербайджано-армянских отношениях в 1918-1920-х годах, а также о деятельности дипломатического представительства Азербайджанской Демократической Республики в Армении в указанный период.

Цель исследования - изучить дипломатические и политические отношения Азербайджанской Демократической Республики с Республикой Армения в 1918-1920 годах с исторической точки зрения, а также выявить и проанализировать исторические и геополитические корни и сущность армяно-азербайджанского Нагорно-Карабахского конфликта.

Ключевые слова: Азербайджанская Демократическая Республика, Армения, политика, дипломатия, международные отношения

\section{Senuber Ganbarova}

Azerbaijan Tourism and Management University

\section{Diplomatic Mission of the Azerbaijan Democratic Republic in Armenia in 1918-1920s}

The bloody military-colonial regime of the Russian Empire failed to destroy the ancient traditions of the statehood of the Azerbaijani people. On May 28, 1918, the Azerbaijan Democratic Republic was created, it was the first secular democratic and legal state in the Muslim East, as well as in the Turkic-Islamic world. The Azerbaijan Democratic Republic was able to exist in a tense and complex socio-political situation for only 23 months. Unfortunately, before reaching the age of two, the independent Republic of Azerbaijan was attacked by the Bolsheviks and was temporarily overthrown. From the day of its formation, the ADR government pursued a flexible foreign policy and sought to establish good-neighbourly relations with all states of the region.

On July 9, 1919, the government of the Azerbaijan Democratic Republic adopted a temporary instruction on the secretariat of the Ministry of Foreign Affairs. During the existence of the republic diplomatic missions of 16 states functioned in its capital city Baku, among them were foreign missions of the USA, Great Britain, France, Italy, etc. 
One of the main issues that constantly attracted the attention of the Azerbaijani government was the issue of borders and relations with close neighbours.

One of the serious obstacles to strengthening the Azerbaijani statehood during this period was the expansionist and aggressive policy of Dashnak Armenia, which tried to appropriate the historical Azerbaijani lands. Armenia made groundless territorial claims to Karabakh, Nakhchivan, Zangezur, etc. Despite the fact that the hostile position of Armenia towards Azerbaijan was traced throughout the entire period of the ADR's existence, the Republic of Azerbaijan still managed to preserve its territorial integrity by the cost of great efforts and losses.

The information on the Azerbaijani-Armenian relations in the 1918-1920s, as well as on the activities of the diplomatic mission of the Azerbaijan Democratic Republic in Armenia during the specified period has been provided in the article.

The aim of the research is to study from a historical point of view the diplomatic and political relations of the Azerbaijan Democratic Republic with the Republic of Armenia in 1918-1920, as well as to identify and analyse the historical and geopolitical roots and essence of the Armenian-Azerbaijani Nagorno-Karabakh conflict.

Keywords: : international trade; RSFSR; the USSR; Ukrainian SSR; the Mediterranean; economic relations

\section{Санубар Ганбарова}

Азербайджанський університет туризму і менеджменту

\section{Дипломатичне представництво Азербайджанської Демократичної Республіки у Вірменії в 1918-1920-і роки}

Кривавий військово-колоніальний режим Російської імперії не зумів знищити найдавніші традиції державності азербайджанського народу. 28 травня 1918 року було створено Азербайджанську Демократичну Республіку, яка була першою світською демократичною та правовою державою на мусульманському Сході, а також в тюрко-ісламському світі. Азербайджанська Демократична Республіка змогла проіснувати в напруженій $і$ складній соціально-політичній обстановці всього 23 місяці. На жаль, не досягнувши дворічного віку, незалежна Азербайджанська Республіка зазнала нападу більшовиків і була тимчасово знищена. 3 дня утворення, уряд АДР проводив гнучку зовнішню політику і прагнув встановити добросусідські відносини з усіма державами регіону.

9 липня 1919 року Урядом Азербайджанської Демократичної Республіки було прийнято тимчасову інструкцію про секретаріат Міністерства закордонних справ. В період існування республіки в її столиці місті Баку функціонували дипломатичні представництва 16 держав, серед яких були іноземні місії США, Великобританії, Франції, Італії і т.д.

Одним з головних питань, які постійно привертали до себе увагу уряду Азербайджану, було питання про кордони і відносини з близькими сусідами.

Однією з серйозних перешкод на шляху зміцнення Азербайджанської державності в цей період стала експансіоністська і агресорська політика Дашнакської Вірменії, яка намагалася привласнити історичні азербайджанські землі. Вірменія пред'являла необгрунтовані територіальні претензії до Карабаху, Нахичевану, Зангезура і т.д. Незважаючи на те, що войовнича позиція Вірменії по відношенню до Азербайджану простежувалася протягом всього періоду існування АДР, Азербайджанській Республіці ціною великих зусиль і втрат все ж вдалося зберегти свою територіальну цілісність.

У статті подано інформацію про азербайджансько-вірменські відносини в 1918-1920-х роках, а також про діяльність дипломатичного представництва Азербайджанської Демократичної Республіки в Вірменії в зазначений період.

Мета дослідження - вивчити дипломатичні і політичні відносини Азербайджанської Демократичної Республіки з Республікою Вірменія в 1918-1920 роках з історичної точки зору, а також виявити і проаналізувати історичні та геополітичні витоки і сутність вірмено-азербайджанського Нагірно-Карабахського конфлікту.

Ключевые слова: Азербайджанська Демократична Республіка, Вірменія, політика, дипломатія, міжнародні відносини 
Вступление

$\mathrm{B}$ ключение в столетия в состав B начале XIX Азербайджана царской России лишило его свободной дипломатической деятельности. С образованием 28 мая 1918 года Азербайджанской Демократической Республики Азербайджан вновь самостоятельно включился в систему международных отношений.

Азербайджанская Республика $-$
Демократическая государство, просуществовавшее с 28 мая 1918 года по 28 апреля 1920 года на территории нынешней Азербайджанской Республики.

Первым шагом во внешней политике молодого государства стало информирование министерств иностранных дел других стран о создании Азербайджанской Республики. Затруднения, связанные с расположением столицы в Гяндже и с созданием представительств в иностранных государствах, стали причиной обращения Министерства иностранных дел Азербайджанской Республики к Османскому государству по этому вопросу.

Переговоры в Батуми, важные для построенных Южно-Кавказским правительством отношений с Турцией, ознаменовали важный этап и во внешней политике уже независимых республик.

Заключённый 4 июня 1918 года «Договор о дружбе между правительствами Османской империи и Азербайджанской Республики" считается первым официальным документом, подписанным Азербайджанской Республикой с иностранным государством. В 4-й статье договора, состоявшего в целом из 11 статей, отражено положение, гласившее, что "Османское правительство берет на себя оказание военной помощи, если будет таковая необходима для укрепления мира и порядка в обеспечение безопасности страны” ( ГААР, ф. 894, on.2, d. 88, л. 1-3).

Целью исследования является изучить дипломатические и политические отношения
Азербайджанской Демократической Республики с Республикой Армения в 19181920 годах с исторической точки зрения, а также выявить и проанализировать исторические и геополитические корни и сущность армяно-азербайджанского Нагорно-Карабахского конфликта.

\section{Результаты исследования.}

Одним из приоритетов для нового государства стала внешняя политика и установление добрососедских отношений со всеми участниками международного общения.

В Декларации Независимости Национального Совета Азербайджана говорилось, что "Азербайджанская Демократическая Республика стремится установить добрососедские отношения со всеми членами международного общения, a, в особенности, с сопредельными народами и государствами" (Акт независимости Азербайджана. Азербайджанская демократическая республика, 2008: 136).

В течение 1918-1920 гг. в Грузии, Турции, Горской Республике, Армении и Туркестане функционировали дипломатические представительства правительства АДР, в Иране - посольство, при Кубанском и Донском правительствах полномочные представители, в Парижской мирной конференции принимала участие полномочная делегация.

В 1919 году, когда азербайджанская дипломатия делала первые шаги, в Баку функционировали дипломатические представительства 16 иностранных государств, в том числе представительства США, Великобритании, Франции, Италии, Швеции, Швейцарии, Бельгии, Ирана, Польши и Украины (Мамедьяров, 2017: 4-5). Подготовленный правительством законопроект «Об образовании дипломатических миссий Азербайджанской Республики в Западной Европе и Америке и упразднении представительства Азербайджана на Парижской мирной 
конференции», был обсужден и принят Парламентом после признания независимости Азербайджана Высшим Советом Антанты. Согласно этому законопроекту, начиная с 1 апреля 1920 г. в Великобритании, Франции, Швейцарии, Италии, США, Германии, России и Польше (Латвии, Литве, Эстонии, Финляндии, Украине, Румынии) предполагалось создание дипломатических представительств (ЦГАОР Аз. ССР, ф. 895, оп. 3, ед. хр. 314, л. 45)

Несмотря на то, что Азербайджанская Демократическая Республика обеспечила для всех своих жителей равенство гражданских прав, их пропорциональное представительство в органах государственной власти и местного самоуправления, правительство соседней Армянской Республики развернуло полномасштабную кампанию этнических чисток с целью изгнания исконного азербайджанского населения из Иревана и других районов, оказавшихся под её контролем. Это спровоцировало появление потоков беженцев, искавших спасения в Азербайджане и других соседних государствах. То есть и тогда, как и сейчас, реализация политической программы армянского национализма создала в регионе гуманитарный катаклизм.

$\mathrm{He}$ ограничиваясь этим, Армянское государство непосредственно, либо под прикрытием разного рода парамилитарных формирований, развернула агрессию против АДР в Нахичевани, Зангезуре, Карабахе и нагорной части Газахского уезда. С другой же стороны, дашнако-большевики под руководством Степана Шаумяна учинили массовое истребление азербайджанского населения в Баку, Шамахе, Губе и других районах.

В этих непростых условиях войны на два фронта Азербайджану, при поддержке Кавказской исламской армии, удалось не только силой оружия освободить 15 сентября 1918 года Баку, но и одержать ряд важных дипломатических побед, включая признание державами Антанты суверенитета АДР над всем Карабахом, где было создано генерал-губернаторство с центром в Шуше, возглавляемое Хосров беком Султановым.

Таким образом, самые напряженные отношения Азербайджанской Демократической Республики в истории ее дипломатии были с Арменией. Еще до создания государства армянские вооруженные формирования совершали массовые убийства местных азербайджанцев на территории современной Армении.

Отметим, что летом 1918 года между Азербайджаном и Грузией были установлены дипломатические отношения на уровне дипломатических представительств, а установление прямых дипломатических отношений между Азербайджаном и Арменией стало возможным только в начале 1919 года. До этого переписка с Арменией велась через дипломатическое представительство Азербайджана в Грузии.

Документы, связанныесдипломатической перепиской между Азербайджаном и Арменией, в основном хранятся в фондах министерств иностранных дел и обороны Азербайджанской Демократической Республики, в фонде Постоянного представительства Азербайджана в Грузии и в фондах Комиссариата иностранных дел Советского Азербайджана.

Несмотря на то, что с момента провозглашения государственной независимости 28 мая 1918 года прошло более полугода, установить прямые дипломатические отношения между Арменией и Азербайджаном не удалось. По этой причине 22 июня министр иностранных дел Азербайджана заявил в письме своему постоянному представителю в Грузии, что он должен проинформировать правительство Армении о том, что следует создать специальную комиссию для установления азербайджано-армянской границы. Если правительство Армении одобрит 
предложение, предлагалось указать место и время встречи для обсуждения дальнейших действий. Однако армянская сторона, игнорируя условия Батумского соглашения и продолжая военную агрессию с целью захвата новых территорий, предъявила территориальные претензии к Нагорному Карабаху.

С 20 октября до конца декабря 1918 года Теймур Макинский был дипломатическим представителем

демократической

Азербайджанской армянском правительстве. Он был избран председателем правления землячества мусульман Эриванской губернии, которое было учреждено в январе 1919 года в Баку с целью защиты проживающих в Эриванской губернии азербайджанцев от армянского деспотизма. Макинский был одним из активных участников национально-освободительного движения, начавшегося в Азербайджане в начале $\mathrm{XX}$ века. Был членом Мусульманской фракции Закавказского сейма, а после его самороспуска стал членом Национального совета Азербайджана (Протоколы заседаний мусульманских фракций Закавказского сейма и Азербайджанского национального совета 1918 г., 2006: 131).

1 февраля 1919 года правительство Армении согласилось на открытие постоянного азербайджанского представительства в Ереване. Одним из первых дипломатов, представлявших интересы Азербайджана в Армении, был Магомед хан Текинский.

М. Текинский родился в 1879 году в Туркестане. Двухлетний Магомед, потерявший родителей во время нападения русских на Ахалтекинскую крепость в 1881 году, был усыновлен полковником российской армии Эхсан ханом Нахичеванским. Мухаммад окончил Первую мужскую гимназию в Тбилиси (Грузия) в 1901 году, а в 1908 году - юридический факультет Новороссийского университета.
M. Текинский принимал участие в деятельности Чрезвычайной следственной комиссии, созданной правительством Азербайджанской Демократической Республики 15 июля 1918 года. Никакой информации о деятельности М. Текинского в период после распада республики не поступало. По словам исследователя А. Тахирзаде, М. Текинский был репрессирован и расстрелян 18 марта 1938 года.

2 апреля 1919 года дипломатический представитель Азербайджана в Армении М. Такинский направил министру иностранных дел М. Джафарову послание о том, что на мероприятии, устроенном в его честь правительством Армении 19 марта, выступавшие говорили о необходимости установить дружеские отношения с Азербайджаном. Текинский также отмечал, что во время встречи с католикосом в Эчмиадзине 18 марта каталикос выразил необходимостьустановлениядружественных отношений между Арменией и мусульманами и пообещал призвать армянский народ жить в мире с мусульманами. М. Текинский отмечал, что Эчмиадзинская церковь и резиденция Католикоса не освещаются из-за отсутствия мазута, добавив, что он обещал послать мазут Католикосу и попросил министра иностранных дел прислать 200 фунтов мазута в бочках, чтобы доставить католикосу. Затем М. Текинский отмечал, что положение беженцев тяжелое и им нужна срочная помощь.

3 мая 1919 года дипломатический представитель Азербайджана в Армении М. Текинский направил телеграмму главе азербайджанского правительства, в которой говорилось, что он направил министру иностранных дел Армении письмо протеста от имени правительства Азербайджана в связи с вторжением армянских войск в Нахичевань.

$\begin{array}{ccr}16 \text { мая } & \text { Текинский } & \text { отправил } \\ \text { зашифрованную } & \text { телеграмму } & \text { главе }\end{array}$ правительства Азербайджана, в которой 
сообщил, что армянские полки атаковали Нахичевань. Чтобы оказать давление на Армению, Текинский предлагал сосредоточить войска награнице с Арменией.

4 июня 1919 года заместитель министра иностранных дел АзербайджанаА.Зиядханов направил телеграмму дипломатическому представителю в Армении М. Такинскому, поручив ему совместно с Иреванским национальным советом собрать информацию о массовых убийствах, совершенных армянами в Иреванской губернии, создать Чрезвычайную парламентскую комиссию по расследованию. В телеграмме также говорилось, что парламент хочет выделить на эти цели 10 миллионов.

В очередной зашифрованной телеграмме, направленной 10 июня Министерством иностранных дел Азербайджана своему дипломатическому представителю в Армении М. Такинскому, поручалось с помощью представителей разрушенных деревень Иреванской губернии, по возможности Карсской области, составить конфиденциальную статистику имен и фамилий, места и возраст жертв. Информация должна была содержать точную информацию об убитых и раненых гражданах, захваченных и разрушенных деревнях. Также было отмечено, что решением правительства Азербайджана было принято решение о создании международной комиссии с участием представителей Великобритании, Италии и других стран для определения масштабов потерь, понесенных азербайджанцами (Пашаев, 2013:152).

Из закодированной телеграммы, направленной M. Текинским министру иностранных дел Азербайджана от 13 июня относительно ситуации в ШарурНахичеванском районе, было видно, что правительство Азербайджана оказывало материальную поддержку вооруженным силам в регионе через своюдипломатическую миссию в Ереване. В телеграмме говорилось, что в этом районе находится 6000 солдат и кавалерии. М. Текинский отмечал, что британцы также признали, что боевая готовность войск не отставала от подготовки армянских войск. Позже М. Текинский писал, что в случае необходимости во время боевых действий численность вооруженных сил в регионе может быть увеличена до 10 тысяч. Дипломат подчеркивал важность сохранения вооруженных сил в ШарурНахичеванском районе на прежних позициях и размещения их в горах на границе с Зангезуром. Текинский также заявлял, что не может полностью гарантировать правильное распределение средств, направляемых для снабжения армии.

Отметим, что правительство Армении, очень обеспокоенное эффективной дипломатической деятельностью М. Текинского, объявило его "персоной нон грата" за его необычайное мужество.

1 октября 1919 года М. Текинский был назначен заместителем министра иностранных дел Азербайджана.

24 августа 1919 года видный азербайджанский писатель и общественнополитический деятель Абдуррахим бек Хагвердиев был назначен дипломатическим представителем Азербайджана в Армении. Абдуррахим бек Хагвердиев много сделал для того, чтобы донести информацию о геноциде против турок в Армении и провинции Карс до Верховного комиссара США, иностранных представительств на Кавказе, чтобы облегчить положение беженцев.

Сотни документов, хранящихся в архивах, подписанных Хагвердиевым, отражают картину того периода.

Следует отметить, что А. Хагвердиев был уволен с дипломатического поста в Армении по собственному желанию. Причиной отставки стало то, что 8 марта 1920 г. он был ограблен армянскими спецслужбами в нейтральной зоне между Грузией и Арменией во время поездки поездом из Тбилиси в Ереван. 
После этого инцидента Абдуррахим бек Хагвердиев пришел к выводу, что работать в Армении невозможно, и попросил немедленно отозвать его с дипломатической должности.

В письме в Министерство иностранных дел Азербайджана он писал: «Я не вижу смысла оставаться здесь после совершенного позорного акта против меня со стороны заранее организованной банды».

Следует отметить, что это преступление, совершенное армянскими преступниками, не было обычным ограблением. Деньги А. Хагвердиева, привезенные из Баку, предназначались не только для нужд дипломатической миссии, но и для предотвращения голода беженцев, сирот и пожилых людей, нашедших убежище в детских домах и больницах в результате нападений армянских вооруженных формирований. [Мустафа, 04.05.2018]

А в марте 1920 года Теймур бек Макинский был назначен на должность дипломатического

Азербайджанской представителя Демократической Республики при армянском правительстве. Судьба Т. Макинского была такой же, как и у его предшественников. В мае того же года Министерство внутренних дел Армении возбудило уголовное дело в отношении сотрудников дипломатической миссии во главе с Т. Макинским по обвинению в пособничестве вооруженному восстанию азербайджанского населения в Зангибасаре. Однако, при содействии постоянного представительства Грузии в Армении он смог тайно покинуть Эривань и 28 мая прибыл в Тифлис.

Дипломатическая миссия сыграла важную роль в регулировании дипломатических отношений между двумя странами, а также в защите интересов турецко-мусульманского населения бывшей Иреванской области в Республике Армения, изучении их положения, предотвращении политики этнической чистки.
Архивные документы показывают, что во времена Азербайджанской Демократической Республики деятельность нашей дипломатической миссии в Армении всегда находилась под постоянным контролем спецслужб Армении.

В апреле политическая ситуация в Азербайджане стала крайне напряженной. Нападения армян на мусульманские села, продвижение Красной армии Советской России на юг привели к кризису, в результате которого 28 апреля АДР была захвачена большевиками и прекратила существование.

В целом, АДР, как молодое государство, на протяжении своего почти двухлетнего существования вела достаточно успешную и активную деятельность по признанию своей независимости международным сообществом. Однако многое зависело от подхода держав-победителей к новому мироустройству, которые зачастую демонстрировали свою медлительность в вопросе признания новых государств.

Советско-большевистский режим, грубо нарушив нормы международного права, оккупировал Северный Азербайджан, в результате чего был положен конец дипломатическим связям де-факто признанной независимой Азербайджанской Демократической Республики в зарубежных странах и представлению ее в системе международных отношений.

Как известно, армянские националисты не оставили попыток отторжения территорий Азербайджана и после советизации Кавказа. Однако, все они провалились. И в регионе был восстановлен мир и спокойствие в единственно возможной форме - сохранения Карабаха, включая его горную и равнинную части, в составе Азербайджана. Армянское население нагорной части этого края пользовалось всеми возможностями, предоставляемыми широкой автономией в форме НКАО. К слову, по общему уровню жизни и основным подушевым показателям НКАО изрядно превосходила средние 
значения по Азербайджанской ССР и Советскому Союзу в целом. Однако, несмотря на все это в конце 1980-х годов армянские националисты вновь начали кампанию по реализации своих территориальных притязаний, переросшую в вооруженную агрессию.

Незаконное применение силы с целью захвата территорий Азербайджанской Республики сопровождалось массовыми этническими чистками, нарушениями международного гуманитарного права, включая акт Ходжалинского геноцида. То есть, налицо всё тот же почерк, что и в начале XX века.

В сложившейся обстановке совершенно очевидно, что устранение последствий военной агрессии со стороны Республики Армения являлось первоочередной и наиболее значимой проблемой, которую Азербайджанская Республика, будучи ответственным членом международного сообщества, пыталась мирно урегулировать путем субстантивных и нацеленных на результат интенсивных переговоров.

Как известно, Совет Безопасности ООН в 1993 году принял 4 резолюции: 822, 853, 874 и 884, где однозначно подтвердил поддержку суверенитета и территориальной целостности Азербайджана, принадлежность НагорноКарабахского региона Азербайджану, осудил агрессию и захват территорий страны, потребовав немедленного, полного и безоговорочного вывода оккупационных сил.

\section{Выводы.}

Подытоживая, следует отметить, что Армения на протяжении долгих лет пыталась всеми возможными способами затянуть процесс урегулирования конфликта, уклоняясь от исполнения своих международных обязательствпонеприменениюсилыилиугрозы силой, разрешению международных споров мирными средствами, уважения нерушимости государственных границ и территориальной целостности государств. Тем не менее, подобная линия поведения завела эту страну в тупик, выход из которого был возможен лишь через нормализацию отношений с соседями и отказ от аннексионистских намерений.

В сентябре 2020 года Азербайджан был вынужден отреагировать на регулярные военные провокации Армении, которая в течение 30 лет оккупировала его исторические земли. Азербайджанский народ доказал всему миру, что Карабах является символом национального достоинства азербайджанцев, и что азербайджанский народ не отступил ни на шаг от мечты о Карабахе.

Процесс национального строительства, осуществляемый Президентом Ильхамом Алиевым на протяжении последних 17 лет, привел к победе Союза Президент-АрмияНарод и изгнанию врага с исторических азербайджанских земель, которые были оккупированы Арменией. Таким образом, в 44-дневной войне Азербайджан победил не только на поле боя, но и в области дипломатии.

\section{БІБЛІОГРАФИНІ ПОСИЛАННЯ}

Акт независимости Азербайджана. Азербайджанская демократическая республика. Сборник статей, посвященный 90-летию Первой республики. - M.: SALAM press, 2008. - 136 c.

ГААР, ф. 894, on.2, d. 88, л. 1-3

Мустафа Н. Посол Абдуррахим бек Хагвердиев был ограблен по требованию правительства Армении. Газета «Азербайджан», 04.05.2018

Мамедьяров Э. Новые задачи, стоящие перед нашей дипломатией: от исторического наследия к будущему Бакинский рабочий.-2017.- 11 июля. - с. 4-5.

Протоколы заседаний мусульманских фракций Закавказского сейма и Азербайджанского национального совета

1918 г. / Под ред. А. А. Пашаева. - Б.: Adiloğlu, 2006, с. 131

Пашаев А. Геноцид, депортации и территориальные претензии армян к азербайджанскому народу (XIX - XX вв.). Баку, 2013, 152 с

ЦГАОР Аз.ССР, ф. 895, оп. 3, ед. хр. 314, л. 45. 


\section{REFERENCES}

Akt nezavisimosti Azerbajdzhana. Azerbajdzhanskaja demokraticheskaja respublika. Sbornik statej, posvjashhennyj 90-letiju Pervoj respubliki. - M.: SALAM press, 2008. - $136 \mathrm{~s}$.

GAAR, f. 894, on.2, d. 88, 1. 1-3

Mustafa N. PosolAbdurrahim bek Hagverdiev byl ograblen po trebovaniju pravitel'stvaArmenii. Gazeta «Azerbajdzhan», 04.05.2018

Mamedjarov Je. Novye zadachi, stojashhie pered nashej diplomatiej: ot istoricheskogo nasledija k budushhemu Bakinskij rabochij. - 2017.- 11 ijulja.- s. 4-5.

Protokoly zasedanij musul'manskih frakcij Zakavkazskogo sejma i Azerbajdzhanskogo nacional'nogo soveta 1918 g. / Pod red. A. A. Pashaeva. — B.: Adiloğlu, 2006, s. 131

Pashaev A. Genocid, deportacii i territorial'nye pretenzii armjan k azerbajdzhanskomu narodu (XIX - XX vv.). Baku, 2013, $152 \mathrm{~s}$.

CGAOR Az.SSR, f. 895, op. 3, ed. hr. 314, 1. 45.

Ganbarova Senuber

Doctoral student., qsenuber@rambler.ru

Стаття надійшла / Article arrived: 05.03.2021

Схвалено до друку / Accepted: 18.04.2021 